\title{
Judges Decisions of Makassar, Palopo, and Masamba Religious Court Over the Islamic Inheritance Law
}

\author{
Andi Sukmawati Assaad ${ }^{1}$, Baso Hasyim²
}

\begin{abstract}
Abstrak: Judges Decisions of Makassar, Palopo, and Masamba Religious Court Over the Islamic Inheritance Law. This study analyzes the results of ijtihad among the judges of the Religious Courts, particularly in the Palopo, Masamba, and Makassar Religious Courts in resolving cases of disputes over the inheritance rights of boys and girls in the Muslim community. Its main purpose is to analyze their method of ijtihad including the legal basis they apply in checking legal facts. This study uses a descriptive-analytic method supported by sociological, normative, and religious approaches. The results of the study concluded that the judges at the Palopo, Makassar, and Masamba Religious Courts have reconstructed the provisions of inheritance law in the Qur'an and the Islamic Law Compilation through their ijtihad. This is indicated by their decision in many cases, among others, to give all inheritance assets to daughters, whereas in the Qur'an and the Islamic Law Compilation the inheritance rights for girls have been determined as $1 / 2$ a portion. Likewise their decision regarding the ratio of inheritance rights between boys and girls, which in the Qur'an, Hadith, and the Compilation of Islamic Law is determined to be 2: 1, reconstructed to be 1: 1 ; the decision to give $1 / 3$ of the inheritance property to the adopted child through a grant or a wasiyat wajibah (will) mechanism, as well as inheritance rights to grandchildren as a substitute for the position of the father or mother.
\end{abstract}

Keywords: Judge’s Decision, Legal Reconstruction, Islamic inheritance law

\begin{abstract}
Abstrak: Putusan Hakim Pengadilan Agama Makassar, Palopo, dan Masamba atas UU Waris Islam. Penelitian ini menganalisis hasil ijtihad para hakim Pengadilan Agama, khususnya di Pengadilan Agama Palopo, Masamba, dan Makassar dalam menyelesaikan perkara perselisihan hak waris anak laki-laki dan perempuan di kalangan masyarakat Muslim. Tujuan utamanya adalah untuk menganalisis metode ijtihad mereka termasuk dasar hukum yang mereka terapkan dalam memeriksa fakta hukum. Penelitian ini menggunakan metode deskriptif analitik yang didukung oleh pendekatan sosiologis, normatif, dan religius. Hasil penelitian menyimpulkan bahwa para hakim Pengadilan Agama Palopo, Makassar, dan Masamba telah melakukan rekonstruksi terhadap ketentuan hukum waris yang ada dalam Alquran dan Kompilasi Hukum Islam melalui ijtihad mereka sendiri. Hal ini ditunjukkan dengan keputusan mereka dalam dalam sejumlah kasus antara lain memberikan semua harta warisan kepada anak perempuan whereas dalam Alquran dan Kompilasi Hukum Islam hak waris bagi anak perempuan telah ditentukan sebesar $1 / 2$ porsi. Demikian pula putusan mereka dalam hal ratio perbandingan hak waris antara anak laki-laki dan perempuan, yang dalam Al-quran, Hadis, dan Kompilasi Hukum Islam ditetapkan 2:1 yang direkonstruksi menjadi
\end{abstract}

\footnotetext{
${ }^{1,2}$ Faculty of Sharia and Law, UIN Alauddin, Makassar, Indonesia

E-mail: ${ }^{1}$ andisukmawatiassaad@uinalauddin.ac.id, ${ }^{2}$ basohasyim@uinalauddin.ac.id
} 
1: 1 ; termasuk keputusan untuk memberikan 1/3 bagian dari harta warisan kepada anak angkat melalui mekanisme hibah atau wasiat al-wajibah, serta hak waris kepada cucu sebagai pengganti posisi ayah atau ibunya.

Kata Kunci: Putusan Hakim, Rekonstruksi Hukum, Hukum waris Islam

\section{Introduction}

In Indonesia, various inheritance law systems can be chosen by members of the community according to their respective cultural and religious characteristics/backgrounds. The inheritance law system is meant to represent one of three legal systems, namely the customary law system, the western civil law system, and the Islamic legal system. ${ }^{1}$ For indigenous Indonesians who are Muslim, Islamic inheritance law ${ }^{2}$ can be their first choice. ${ }^{3}$ Meanwhile, non-Muslim Indonesian citizens can use local customary law or the Western Civil Law (BW) legal system. The existence of this difference in the application (legal pluralism) indirectly encourages the Indonesian government to try to unite and integrate it into one inheritance system that is following the characteristics of society based on Pancasila and the 1945 Constitution.

This is consistent with what Teuku Muhammad Radhie, former Head of the Ministry of Justice's National Legal Development Agency (BPHN) stated, that Indonesia needs to have a unified legal system for all citizens. ${ }^{4}$ This is because the understanding of modern law

${ }^{1}$ M. Yasin al Arif, 'Internalization of Maqasid Al-Syari'ah in Judge's Decision' (presented at the 1st Raden Intan International Conference on Muslim Societies and Social Sciences (RIICMuSSS 2019), Atlantis Press, 2020), pp. 206-10 (p. 206) <https://doi.org/10.2991/ assehr.k.201113.039>.

2 Supriyadi Supriyadi, 'Pilihan Hukum Kewarisan dalam Masyarakat Pluralistik (Studi Komparasi Hukum Islam dan Hukum Perdata)', AL-'ADALAH, 12.1 (2015), 553-68 see also <https://doi.org/10.24042/adalah.v12i1.235>; Arofi Pratama Putra Aslah, 'Kajian Yuridis Timbulnya Hak Mewaris Menurut Hukum Islam', LEX ADMINISTRATUM, 5.2 (2017) <https:// ejournal.unsrat.ac.id/index.php/administratum/article/view/15404>.

${ }^{3}$ Sakirman Sakirman, 'Konvergensi Pembagian Harta Waris Dalam Hukum Islam.', $A L$ 'ADALAH, 13.2 (2016), 155-64 <https://doi.org/10.24042/adalah.v13i2.1853>; see also Kiki Adnan Muzaki, Asep Saepudin Jahar, and Muhammad Amin Suma, 'Reform of The Law of Inheritance in Turkey and Tunisia', AL-'ADALAH, 17.2 (2020), 249-68 (p. 250) <https://doi. org/10.24042/adalah.v17i2.8031>.

${ }^{4}$ F. C. Susila Adiyanta, 'Pembaruan Hukum Nasional: Pruralisme, Unifikasi Hukum, Dan 
requires a unification of laws in a country and tries to avoid an atmosphere of legal pluralism. This unification of law is very likely to be implemented because the development of law adopted in Indonesia is based on the concept of the archipelago, meaning that there is only one legal entity that applies to all Indonesian citizens, namely the national legal system.

GBHN 1998, which is a legal product during the reform period, provides direction for national legal policies in the form of a comprehensive and integrated arrangement of the national legal system, strengthening and respecting religious and customary law, updating colonial inheritance laws and national laws that are discriminatory, including eliminating discrimination, gender injustice or other inequality that is incompatible with the spirit of reform.

On the other hand, around the 1980s, Munawir Sjadzali, then Minister of Religion of the Republic of Indonesia, put forward the idea of the need for the re-actualization of Islamic law, especially in the field of inheritance law. The main problem that he addresses in his idea is "if necessary" the inheritance portion for men and women from section 2: 1 is changed to 1: 1 . This is based on rational arguments as well as realities in a society where the 1: 1 portion is for men. and women are seen as relevant to the concept of justice in modern times. Although his idea seems simple, it is very basic, causing a prolonged polemic in the community. Indeed, the consequences of the distribution of inheritance based on gender equality will lead to new interpretations of the law for men and women, which in this case are represented by sons and daughters, husbands and wives, fathers and mothers, grandparents, grandson and granddaughter and so on.

From the perspective of legal politics, judge's ijtihad ${ }^{5}$ is one of

\footnotetext{
Hubungan Kewenangan Antara Pemerintah Pusat Dengan Pemerintah Daerah', Administrative Law and Governance Journal, 2.1 (2019), 93-105 <https://doi.org/10.14710/alj.v2i1.93-105>; see also Muhammad Noor, 'Unifikasi Hukum Perdata Dalam Pluralitas Sistem Hukum Indonesia', Mazahib, 13.2 (2014) <https://doi.org/10.21093/mj.v13i2.385>.

${ }^{5}$ Susi Susanti, 'Modifikasi Ijtihad Hakim Pengadilan Agama Dan Relevansinya Terhadap Hukum Islam', Al-Qisthu: Jurnal Kajian Ilmu-Ilmu Hukum, 17.1 (2019), 27-33 <https://doi. org/10.32694/010700>.
} 
the solutions in overcoming the legal vacuum. Whatever and whatever form the decisions they make will still have legal force because they are taken based on concrete facts and through careful study and are decided based on the principles of justice, freedom, honesty, and impartiality.

In Law Number 7 of 1989 which was amended by Law Number 3 of 2006 and lastly amended by Law Number 50 of 2009, it was stated that the Religious Court is one of the judicial institutions in Indonesia that has the authority to uphold Islamic law and justice for Muslims in certain civil cases. In its development, the Religious Courts in Indonesia have been integrated and have an equal position with other judicial institutions under the Indonesian Supreme Court. Based on the same regulation, it is also regulated that the authority of the Religious Courts is not only limited to handling matters of marriage, inheritance, wills, endowments, grants, sadaqah, and zakat but has been expanded to solve various cases in the field of Islamic economics.

As the role of the judge's decision is so important in the law enforcement process, therefore, on this occasion, the researcher tries to carry out research and studies on it to get a comprehensive picture of how judges carry out reconstruction of law, particularly of Islamic inheritance law through the ijtihad mechanism they carry out in making legal decisions to settle the cases submitted to them.

\section{Method}

This research is classified as descriptive, qualitative, and analytical field research, which is supported by sociological, normative, and religious approaches. The focus/object of this research is the verdict of the Makassar, Palopo, and Masamba Religious Courts on inheritance issues which include: legal considerations, the ijtihad method, and the format of decisions made to resolve cases involving certain parties. The data collection methods used were in-depth interviews, taken from three judges of the three Religious courts, observation, and documentation. In the analysis stage, the method used is deductive, which is an analytical technique that starts from general theoretical concepts to be tested with 
facts in the field that are specific in nature. From the results of this analysis, it can be understood how the judges reconstruct legal provisions to adapt to the existing situation and conditions when the verdict was made.

\section{The Concept of Inheritance Rights for Men and Women in Islamic Law}

According to Amin Summa, inheritance is the transfer of ownership of a property from a deceased person to his family who will receive the inheritance and regulates the portion or size of the portion of each heir including the time of distribution. ${ }^{6}$ The law of inheritance regulates the transfer of property rights (tirkah) from a person who passes away to the heirs to determine who is entitled to the existing inheritance and how much is the portion of each. ${ }^{7}$ The transfer of ownership generally occurs in the context of kinship, although in certain cases it can also involve other parties who do not belong to the family. ${ }^{8}$

\section{The beneficiaries}

The majority of Ulama (Jumhur ulama) agree to stipulate 25 people of close relatives that can receive the inheritance, namely:

a. Fifteen male heirs, namely:

1) Sons (al-ibn)

2) Grandsons (ibn al-ibn) and so on down the male line, also Grandsons/the sons of the daughter (bin al bint);

3) Biological Father (al-ab);

4) Grandfather from the paternal line (al-jadd min jihatil-ab)

5) Biological brothers (al-akh al-syaqiq);

${ }^{6}$ Muhammad Amin Summa, Hukum Keluarga Islam Di Dunia Islam (Jakarta: PT. Raja Presindo, t.t), p. 108.

7 The heirs are people who are still alive and who will receive the inheritance. See Islamic Law Compilation Book II Part II Article 171 point b.

${ }^{8}$ A. Pitlo, Het Efrecht Noar Het Nederlands Burgelijk Wet Boek (Translator: M.Isa Arif, Edition I \& II (Jakarta: Intermasa, t.t), p. 1. 
6) Half-brother of the same father (al-akh li al-ab);

7) Half-brother of the same mother (al-akh li al-umm)

8) Nephews / The sons of biological brothers (ibn al-akh al-syaqiq)

9) Nephews / the sons of half-brother from the same father (ibn al-akh li al-ab)

10) Biological Uncles (al-'amm al-syaqiq)

11) Step uncles/father's half-brothers from the same father (al-'amm li $a l-a b$ )

12) Sons of the biological uncle (ibn al-'amm al syaqiq)

13) Sons of Step uncles/father's half-brothers from the same father (ibn al'amm).?

14) Husband (zawj);

15) A Man who frees his slave. ${ }^{10}$

b. Ten of the female heirs such as:

1) Daughters (al-bint)

2) Granddaughters (bint al-ibn)

3) Biological Mother (al-umm);

4) Grandmother from the paternal line (al-jaddah min jihat al-ab)

5) Grandmother from the maternal line (al-jaddah min jihat alumm).

6) Biological sisters (al-ukht al-syaqiqah)

7) Half-sister of the same father (al-ukht li al-ab)

8) Half-sister of the same father (al-ukht li al-umm)

9) Wife (Zaujah);

10) Female who free her slaves (al-Wala). ${ }^{11}$

\footnotetext{
${ }^{9}$ Ahmad Rofiq, Fiqih Mawaris (Jakarta: PT Raja Grafindo Persada, 1998), pp. 49-50.

${ }^{10}$ Ibn Rusyd, Bidayah Al-Mujtahid, (Cairo: Matba'ah al-Mu'ahad, 1935), p. 333.

${ }^{11}$ Ibn Rusyd, p. 333.
} 
In general, the 25 heirs of the above-group can be divided into two groups, namely the heirs of Sababiyah and the heirs of Nasabiyah:

1. The heirs of Sababiyah, that is the heirs that arise from an inheritance relationship due to certain reasons, namely:

a. Because of marriage (al-mushaharah)

b. For freeing a slave (al-wala) or because there is a promise to help each other.

2. The heirs of Nasabiyah, also called Zawil furudh or Ashabul furudl, that is the heirs who are entitled to a share of the inheritance because of their family relationship (blood or descent) with the heir. The heirs of Nasabiyah is divided into three types, namely: furu'al-mayyit, ushul al-mayyit, and al-hawasyi.

a. Furu'al-Mayyit, a group of heirs from the descendants of almuwarrits (heir), is often called a branch group (al-bunuwwah). This group is the closest heirs, and they take precedence in receiving the inheritance. The heirs included in this group are

1) Sons (al-ibn)

2) Daughters (al-bint)

3) Grandsons and granddaughters (ibn al-ibn and bint al-ibn) and so on down the male line.

b. Ushul Al-Mayyit, that is a group of heirs who have an upward linear relationship with the heir, namely:

1) Biological Father (al-ab);

2) Biological Mother (al-umm);

3) Grandfather from the paternal line (al-jadd min jihatal-ab)

4) Grandmother from the paternal line (al-jaddah min jihat $a l-a b)$

5) Grandmother from the maternal line (al-jaddah min jihat al-umm).

c. Al-Hawasyi, a group of heirs who have a horizontal relationship with the heir, such as:

1) Biological brothers (al-akh al-syaqiq); 
2) Biological sisters (al-ukht al-syaqiqah)

3) Half-brother of the same father (al-akh li al-ab);

4) Half-sister of the same father (al-ukht li al-ab)

5) Half-brother of the same mother (al-akh li al-umm)

6) Half-sister of the same father (al-ukht li al-umm)

7) Nephews/the sons of biological brothers (ibn al-akh alsyaqiq)

8) Nephews/the sons of half-brother from the same father (ibn al-akh li al-ab)

9) Grandsons/the sons of the daughter (bin al bint);

10) Biological Uncles (al-'amm al-syaqiq)

11) Step uncles/father's half-brothers from the same father (al-'amm li al-ab)

12) Sons of the biological uncle (ibn al-'amm al syaqiq)

13) Sons of father's half-brothers from the same father (ibn al-'amm li al-ab)

In terms of distance and closeness to kinship relations, the heirs can be categorized into two groups such as:

a. Close Relatives consist of:

1) Zawil Furudl or Ashabul furudl, that is the heirs whose share has been determined and can receive an inheritance. In general, the heirs of ashab al-furudl are women, while male heirs receive the remaining portion ('asabah), except for the father, grandfather and husband. Perhaps this was intended as a revolutionary step for the Islamic religion in changing the value system of the Jahiliyah society which looked down on and did not give women any share of the inheritance. They are even treated as things, which can only be owned, but cannot have.

2) Zawil Ashabah (recipient of the remainder).

b. Zawil Arham, the distant relatives who have not a certain share and could not receive the remainder (asabab), as like the sons and the daughters from transmitting daughters 


\section{Al-Furudh Al-Muqaddarah (Determined portions) and the kinds}

The word al-furudh is the plural form of the word fardh which means part (provision). Al-Muqaddarah means determined. So al-furudh al muqaddarah means the portions that have been determined in the Qur'an. These parts will be received by the heirs according to the proximity of the kinship relationship.

Six kinds of al-furudhal-muqaddarah are regulated in the Qur'an, namely: a. Half / half $(1 / 2=$ al-nisf $)$ b. One-third $(1 / 3=$ al-tsuluts $) c$. Quarter $(1 / 4=$ al-rubu' $)$ d. One-sixth $(1 / 6=$ al-sudus $)$ e. Eighth $(1 / 8$ = al-sumun $) \mathrm{f}$. Two thirds $(2 / 3=$ al-tsulutsain $)$

\section{The Inheritance of Ashab al-Furudh and their Rights}

The explanation below is no longer separated between the heirs of the Nasabiyah and the Sababiyah as they are both ashab al-furudh. In general, the heirs of ashab al-furudh are women, while male heirs who receive a certain share are the father, or grandfather, and husband. The rest receives the remaining portion (asabah). The rights received by the heirs of ashab al-furudh are:

a. A daughter is entitled to receive shares of $1 / 2$ if she is alone not with brothers, if two or more daughters, they receive $2 / 3$ if they are not a brother.

b. male-line granddaughters, have the right to receive $1 / 2$ if alone, not with the grandchildren, and are not obstructed (Mahjub); $2 / 3$ if two or more people, not with grandchildren and are not obstructed (Mahjub); $1 / 6$ as a compliment, and 2/3 if they are with a daughter, and there are no grandchildren and are not obstructed (Mahjub). If there are two or more daughters, they do not get a share.

c. A Mother has the right to receive a portion of $1 / 3$ if there are no children or grandchildren (far'u waris) or two or more siblings; $1 / 6$ if there is a far'u waris or with two or more siblings; $1 / 3$ of the remaining, in the case of Gharrawain, namely if the heirs consist of husband/wife, mother, and father only. 
d. A father has the right to receive a share of $1 / 6$ if there are sons or grandchildren $1 / 6$ + leftovers, if together with daughters or granddaughters from male lines. If the father is with the mother, each $1 / 6$ if there are children, grandchildren, or siblings of two or more; $1 / 3$ for the mother and the father receives the remainder, if there are no children, grandchildren, or siblings of two more, the Mother receives the remaining $1 / 3$, while the remaining is for the father after being taken for the husband or wife.

e. Grandmother, if not obstructed (Mahjub) has the right to receive a share of $1 / 6$ if alone; $1 / 6$ is divided equally if the grandmother is more than one person and equal in level.

f. Grandfather, if not obstructed (Mahjub)., has the right to receive $1 / 6$ if with sons or grandchildren; $1 / 6+$ remaining, if with children or granddaughters without sons; $1 / 6$ or muqasamah (share equally) with siblings or half brother, after being taken for other heirs; $1 / 3$ or muqasamah with siblings or half brother, if there are no other heirs.

g. A biological sister, if not obstructed (mahjub), has the right to receive a share of $1 / 2$ if she is alone and not with her brother; $2 / 3$ for two or more, if not with a brother.

h. A half-sister of the same father, if not obstructed (mahjub), has the right to receive $2 / 3$ if she is alone not with her brother of the same father; $2 / 3$ for two or more persons if not with brother. 1/6 if with a single sibling sister, as a complement to $2 / 3$.

i. A half-sister/brother of the same mother has the same position. If not obstructed (mahjub), they are entitled to receive a share of $1 / 6$ if alone; $1 / 3$ for two or more persons, $1 / 3$ with siblings, when together with heirs and mothers (musyarakah)

j. A Husband is entitled to receive shares of $1 / 2$ if they do not have children or grandchildren; $1 / 4$ if they are with children or grandchildren. $\mathrm{k}$. Wife, are entitled to receive shares: $-1 / 4$ if they do not have children or grandchildren. $1 / 8$ if with children or grandchildren; 
k. Wife has the right to receive $1 / 4$ if she does not have children or grandchildren; $1 / 8$ if she is with children or grandchildren. ${ }^{12}$

\section{The Role of the Judge in the Judicial Process}

In the concept of state law (rechtstaat), judicial power is a state body that has the authority to judge and to determine the content, principles, and strength of law in a case. The exercise of judicial power is manifested by judges in the act of examining and assessing certain behaviors or situations/conditions in a legal case and then resolving them through decisions made impartially and based on existing legal rules. ${ }^{13}$ Judges have two roles at once: first, as a person who adjudicates cases in court, and second, as a person who is considered to have wisdom. ${ }^{14}$

The judge has to give the fairest decision in every case or conflict presented to him. Before making a decision, a judge must carefully study everything related to the case he faces, both in terms of legal standing, legal relations, and legal judgments. In resolving disputes or conflicts, he must be independent, impartial, free from conflicts of interest, and make decisions based on applicable law. ${ }^{15}$ In making decisions, he must always consider philosophical, sociological, and juridical aspects so that the decisions he makes can be juridically, and morally accountablefollowing the provisions of laws and regulations and following moral values of the society. ${ }^{16}$ Judges' decisions will be highly respected and dignified if they reflect professionalism and uphold a sense of justice

${ }^{12}$ Rofiq, pp. 49-50.

${ }^{13}$ Lili M. Rasjidi \& Ira Thania, Dasar-Dasar Filsafat Dan Teori Hukum (Bandung: Citra Aditya Bakti, 2004). also Article 24 (1) the 1945 Constitution: "Judicial power is an independent power to administer the judiciary to uphold law and justice" and Article 24 (2): "The implementation of the implementation of judicial power is carried out by a Supreme Court and judicial bodies under it, namely in the judiciary, religious courts, state administrative courts by a constitutional court", and Article 18 of the Law of Judicial Power Number 48 of 2009: "Judicial power is exercised by a Supreme Court and judicial bodies under it within the domain of general courts, religious courts, military courts, and state administrative courts and by a Constitutional Court".

${ }^{14}$ Hasbi Ashiddieqie in Dudu Duswara Machmuddin, 'Peranan Keyakinan Hakim Dalam Memutus Suatu Perkara Di Pengadilan’ (Jakarta: IKAHI, 2006), p. 52.

${ }^{15}$ Ira Thania, pp. 93-94.

${ }^{16}$ Lilik Mulyadi, 'Pergeseran Perspektif Dan Praktek Dari Mahkamah Agung Mengenai Putusan Pemidanaan', Majalah Hukum Varia Peradilan, p. 21. 
and truth. For this reason, before making a decision, a judge needs to consider his conscience about whether his decision that will be passed will be fair and beneficial to all seekers of justice or not. Thus, every judge must have a broad and intelligent mind and a clear conscience. ${ }^{17} \mathrm{He}$ is also required to work professionally, cleanly, fairly, and wisely, and to have a high sense of humanity. Judges must not overreact in responding to various responses from various parties such as criticizing, belittling, even making fun of, which is sometimes carried out in harsh and disproportionate language. ${ }^{18}$

Judges have a strategic role and function in upholding truth and justice. It has the mandate and authority to interpret and implement laws and regulations based on the principles of material or substantive law, and the values of justice that live in society. ${ }^{19}$ Normative justice here refers to justice following the law and moral justice, a sense of justice based on the judge's conscience. ${ }^{20}$

\section{The Position of Jurisprudence in the Legal System in Indonesia}

The word Jurisprudence comes from the Dutch language, jurisprudentie, or jurisprudence in English, which means the study of the main principles of society and state law. In modern times, science can be defined as the study of the main elements of a particular legal system, or it can be interpreted as the study of the legal system in general which includes the principles of natural law and state law. More concretely, jurisprudence is the study of general and fundamental elements of the legal system. ${ }^{21}$

Jurisprudence can also be understood as a compilation of judges' decisions from the court of the first level to the highest level (MA)

${ }^{17}$ Rudi Suparmono, 'Peran Serta Hakim Dalam Pembelajaran Hukum', Majalah Hukum Varia Peradilan, 2006, p. 50.

${ }^{18}$ Ahmad Rifai, Penemuan Hukum Oleh Hakim Dalam Perspektif Hukum Progresif, 2nd edn (Jakarta: Rosda Karya, 2011), p. 3.

19 Satjipto Rahardjo, Wajah Hukum Di Era Reformasi, (Bandung: Citra Aditya Bhakti, 2000), p. 263.

${ }^{20}$ Utrecht, Pengantar Dalam Hukum Indonesia (Jakarta: Ichtiar, 1983), p. 216.

${ }^{21}$ Bryan A. Garner, Black Law Dictionary (New York: Thomson-West Group, 2004), p. 871. 
which is one of the sources for the formation or application of the law in Indonesia. In the event of a legal dispute between fellow citizens or between citizens and the authorities, the judge has the right to accept, examine, including making decisions independently based on legal facts to uphold law and justice, as guaranteed by the 1945 Constitution. ${ }^{22}$ Jurisprudence is also understood as a judge's decision in a judicial institution that has permanent legal force and is justified by the Indonesian Supreme Court. Not all judges' decisions at the first level or the appellate level can be categorized as jurisprudence unless the decision has been reviewed through a complete examination under jurisprudential standards and has obtained notes/recommendations from the Supreme Over the past five years, judges at the Makassar Religious Court have decided around 200 cases relating to inheritance issues. Some of these cases were rejected and some were accepted. Some were resolved amicably at the Court of First Instance, some of which were approved at the Court of Appeal Level, and several other cases were resolved at the cassation level (the Supreme Court). ${ }^{23}$ On the other hand, the Masamba Religious Court has rejected five cases of inheritance, some have been rejected at the first level courts, some are at the appeal level, and some are at the cassation level. ${ }^{24}$ Meanwhile, for the Palopo Religious Court, the number of inheritance cases that have been submitted in the last five years has reached 50 cases, some of which were decided through peaceful dispute resolution at the first level, others were continued. to the appeal and cassation level. ${ }^{25}$

\section{The Judges' Decisions on Inheritance in Makassar, Masamba, and Palopo Religious Courts}

Based on the results of research, there are indications that the Judges in the three Religious Courts have reconstructed Islamic inheritance

${ }^{22}$ Gandasubrata, HR. Purwoto S, Renungan Hukum (Jakarta: Ikatan Hakim Indonesia, 1998), p. 292.

${ }^{23}$ Muh. Arief, a judge of Makassar Religious Court, 2018.

${ }^{24}$ Abd. Hizam Monoarfa, a judge of Masamba Religious Court, 2018.

${ }^{25}$ Muh. Thoyyib, The Head of Palopo Religious Court, 2018. 
law as reflected in their various decisions which are different from what is written in the al-Qur'an, al-Hadith, and Compilation of Islamic Law. By using ijtihad as a legal basis in resolving inheritance cases submitted to them, the judges at the Palopo, Makassar, and Masamba Religious Courts have made an equal formula in the distribution of inheritance between boys and girls (1: 1) even though in the Qur'an and Compilation of Islamic law, the inheritance rights of a girl are $1 / 2$ that of a boy (1:2). They did this because the 2: 1 ratio between boys and girls was seen as no longer in line with the sense of justice. Besides, the panel of judges also decided to grant inheritance rights through the will of al-wajibah to adopted children, and also to grandchildren as a substitute for the position of their father, and grandchildren and daughters of daughters who replaced their mother. These last three issues are not explicitly regulated either in the Qur'an, Hadith, or in the Compilation of Islamic Law. As a solution, therefore, the judges in the three religious courts decided to grant $1 / 3$ of the inheritance right through wasiyat al-wajibah (the testament). Now this decision has become the jurisprudence that is referred to by judges in many Religious courts. ${ }^{26}$

\section{Case Settlement Method}

In completing the distribution of inheritance for men and women, the Judges at the Makassar, Masamba, and Palopo Religious Courts used the applicable legal rules in Indonesia, both classified as formal law, such as the Law on the Religious Courts and the Religious Courts. Herzien Indlandsch Reglement, as well as those classified as material law such as the Compilation of Islamic Law, Fiqh Books, and Ulama's opinion.

Within the Makassar Religious Court, the judges decide cases of distribution of inheritance by referring to the Compilation of Islamic Law and the results of their ijtihad. They also put forward efforts to resolve

${ }^{26}$ Habiburrahman, Rekonstruksi Hukum Kewarisan Islam Di Indonesia (Jakarta: Kementerian Agama, 2011), p. 100. 
cases of inheritance through non-litigation mechanisms and encourage parties to pursue peaceful settlement of cases and refer to the principles of universal Islamic law, a sense of justice, and human rights. ${ }^{27}$

It is more or less the same as the phenomenon above, the judges at the Masamba Religious Court, in adjudicating a case, not only rely on the Compilation of Islamic Law as the main guideline but also use the norms of customary law and traditions that live and apply in the local community. The use of customary and traditional law norms in addition to the determined material laws, in turn, becomes a separate contribution to the development of Islamic Fiqh in the country, especially in the field of inheritance. Apart from efforts to resolve cases by litigation, judges at local institutions also offer solutions through mediation methods, even this is a priority so that not all cases that come in have to end up with winning or losing decision. ${ }^{28}$

Not much different from what was done by the judges at the Makassar and Masamba Religious Courts, Judges in the Palopo Religious Court, in considering and deciding inheritance cases, also used legal norms that were sourced from the Civil Code and the Compilation of Islamic Law. However, it is not uncommon for them to prioritize other legal solutions, such as taking non-litigation measures or peaceful settlements. These two kinds of approaches are the main choice of judges when solving a case related to inheritance issues. ${ }^{29}$

\section{Conclusion}

The distribution of inheritance rights is currently still a matter of debate and an interesting polemic among the Muslim community, including among judges at the Religious Courts. This can be seen from the ijtihad method and legal reasons used by the Judges of the Makassar, Masamba, and Palopo Religious Courts in resolving the distribution of inheritance rights for men and women. The results showed that the

\footnotetext{
${ }^{27}$ Muh. Arief,.

${ }^{28}$ Abd. Hizam Monoarfa.

${ }^{29}$ Muh. Thoyyib.
} 
judges in the 3 (three) Religious Courts did not only refer to the formal laws in force in Indonesia such as the Law on the Religious Courts, and the Herzien Indlandsch Reglement, but also considered material laws such as the Islamic Law Compilation, the book fiqh, and the views of the scholars as a source of law. Specifically in the field of inheritance law, as seen in several existing decisions, judges tend to use the results of their ijtihad and reconstruct the provisions contained in the Compilation of Islamic Law, the books of figh, and even the Qur'an itself. The results of the Ijtihad of the judges then received a positive response from religious judges in all Religious Courts in Indonesia and were used as material for legal considerations (jurisprudence) in determining the portion of inheritance rights for boys and girls.

\section{Bibliography}

A. Pitlo, Het Efrecht Noar Het Nederlands Burgelijk Wet Boek (Translator: M.Isa Arif, Edition I \& II (Jakarta: Intermasa, t.t)

Abd. Hizam Monoarfa, a judge of Masamba Religious Court, 2018

Adiyanta, F. C. Susila, 'Pembaruan Hukum Nasional: Pruralisme, Unifikasi Hukum, Dan Hubungan Kewenangan Antara Pemerintah Pusat Dengan Pemerintah Daerah', Administrative Law and Governance Journal, 2.1 (2019), 93-105 <https://doi.org/10.14710/alj.v2i1.93105>

Ahmad Rifai, Penemuan Hukum Oleh Hakim Dalam Perspektif Hukum Progresif, 2nd edn (Jakarta: Rosda Karya, 2011)

Arif, M. Yasin al, 'Internalization of Maqasid Al-Syari'ah in Judge's Decision' (presented at the 1st Raden Intan International Conference on Muslim Societies and Social Sciences (RIICMuSSS 2019), Atlantis Press, 2020), pp. 206-10 <https://doi.org/10.2991/ assehr.k.201113.039>

Aslah, Arofi Pratama Putra, 'Kajian Yuridis Timbulnya Hak Mewaris Menurut Hukum Islam', LEX ADMINISTRATUM, 5.2 (2017) $<$ https://ejournal.unsrat.ac.id/index.php/administratum/article/ view/15404> 
Bryan A. Garner, Black Law Dictionary (New York: Thomson-West Group, 2004)

Gandasubrata, HR. Purwoto S, Renungan Hukum (Jakarta: Ikatan Hakim Indonesia, 1998)

Habiburrahman, Rekonstruksi Hukum Kewarisan Islam Di Indonesia (Jakarta: Kementerian Agama, 2011)

Hasbi Ashiddieqie in Dudu Duswara Machmuddin, 'Peranan Keyakinan Hakim Dalam Memutus Suatu Perkara Di Pengadilan' (Jakarta: IKAHI, 2006)

Ibn Rusyd, Bidayah Al-Mujtahid, (Cairo: Matba'ah al-Mu'ahad, 1935)

Ira Thania, Lili M. Rasjidi \&, Dasar-Dasar Filsafat Dan Teori Hukum (Bandung: Citra Aditya Bakti, 2004)

Lilik Mulyadi, 'Pergeseran Perspektif Dan Praktek Dari Mahkamah Agung Mengenai Putusan Pemidanaan', Majalah Hukum Varia Peradilan,

Muh. Arief, a judge of Makassar Religious Court, 2018

Muh. Thoyyib, The Head of Palopo Religious Court, 2018

Muhammad Amin Summa, Hukum Keluarga Islam Di Dunia Islam (Jakarta: PT. Raja Presindo, t.t)

Muzaki, Kiki Adnan, Asep Saepudin Jahar, and Muhammad Amin Suma, 'Reform of The Law of Inheritance in Turkey and Tunisia', AL-'ADALAH, 17.2 (2020), 249-68 <https://doi.org/10.24042/adalah.v17i2.8031>

Noor, Muhammad, 'Unifikasi Hukum Perdata Dalam Pluralitas Sistem Hukum Indonesia', Mazahib, 13.2 (2014) <https://doi.org/10.21093/ mj.v13i2.385>

Rofiq, Ahmad, Fiqih Mawaris (Jakarta: PT Raja Grafindo Persada, 1998)

Rudi Suparmono, 'Peran Serta Hakim Dalam Pembelajaran Hukum', Majalah Hukum Varia Peradilan, 2006

Sakirman, Sakirman, 'Konvergensi Pembagian Harta Waris Dalam Hukum Islam.', AL-'ADALAH, 13.2 (2016), 155-64 <https://doi. org/10.24042/adalah.v13i2.1853>

Satjipto Rahardjo, Wajah Hukum Di Era Reformasi, (Bandung: Citra Aditya Bhakti, 2000) 
Susanti, Susi, 'Modifikasi Ijtihad Hakim Pengadilan Agama Dan Relevansinya Terhadap Hukum Islam', Al-Qisthu: Jurnal Kajian IlmuIlmu Hukum, 17.1 (2019), 27-33 <https://doi.org/10.32694/010700> Utrecht, Pengantar Dalam Hukum Indonesia (Jakarta: Ichtiar, 1983) 